\title{
THE FIRST REPORT OF CRYPTOCARYOXYLON FROM THE NEOGENE (EARLY MIOCENE) OF EURASIA (EASTERN MEDITERRANEAN: LESBOS AND LEMNOS ISLANDS, GREECE)
}

\author{
DIMITRA MANTZOUKA
}

National and Kapodistrian University of Athens, Faculty of Geology and Geoenvironment, Department of Hist. Geology - Paleontology, Panepistimioupoli Zographou, 15784 Athens, Greece; e-mail: dmantzouka@geol.uoa.gr,dmantzouka@yahoo.gr.

Mantzouka, D. (2018): The first report of Cryptocaryoxylon from the Neogene (early Miocene) of Eurasia (Eastern Mediterranean: Lesbos and Lemnos Islands, Greece). - Fossil Imprint, 74(1-2): 29-36, Praha. ISSN 2533-4050 (print), ISSN 2533-4069 (on-line).

\begin{abstract}
Two specimens of fossil lauraceous woods from the Cainozoic (early Miocene) of Greece (southern part of Lesbos Island and central-eastern part of Lemnos Island) were studied. Their microscopic characteristics revealed two different kinds of fossil lauraceous woods with a different distribution of idioblasts (oil and/or mucilage cells) which do not correspond to the pattern in Laurinoxylon. The determination as two new species of Cryptocaryoxylon (C. lesbium sp. nov., C. lemnium sp. nov.) is proposed. A discussion of described Cryptocaryoxylon species, which have a worldwide distribution, is also presented. The assignment of the two Greek specimens to the genus Cryptocaryoxylon and their nomination as the first occurrences of this genus from the Neogene of Eurasia is supported.
\end{abstract}

Key words: Cryptocaryoxylon, Cryptocaryoxylon lesbium, Cryptocaryoxylon lemnium, Lauraceae, fossil wood anatomy, oil and/or mucilage cells, Lesbos Island, Lemnos Island, Greece, UNESCO Global Geoparks, early Miocene

Received: September 14, 2017 | Accepted: February 16, 2018 | Issued: August 31, 2018

\section{Introduction}

Representatives of Cryptocaryoxylon have been reported in the literature only three times: a) type species $C$. gippslandicum LEISMAN (Leisman 1986) from the late Eocene-Oligocene (39 Ma) of Australia, b) C. hancockii WheELER et MANCHESTER, C. meeksii WheEler et MANChEster and C. radiporosum WheEler et MANCHESTER (Wheeler and Manchester 2002) from the middle Eocene of Oregon, USA and c) C. oleiferum RAMOS, BREA et KRÖHLING which was recently found in the Late Pleistocene of Argentina (Ramos et al. 2015).

Leisman (1986) based the diagnosis of Cryptocaryoxylon on the characteristics of the extant genus Cryptocarya, the wood anatomy had been fully described previously by Richter (1981).

\section{Localities and geology}

The specimens described herein are from a new locality in the southern part of the Island of Lesbos and from the Central-Eastern part of Lemnos Island in the Aegean Sea in north-eastern Greece (Text-fig. 1).

New plant fossiliferous localities from the southern part of Lesbos Island (Polichnitos Region) were discovered in 2011,

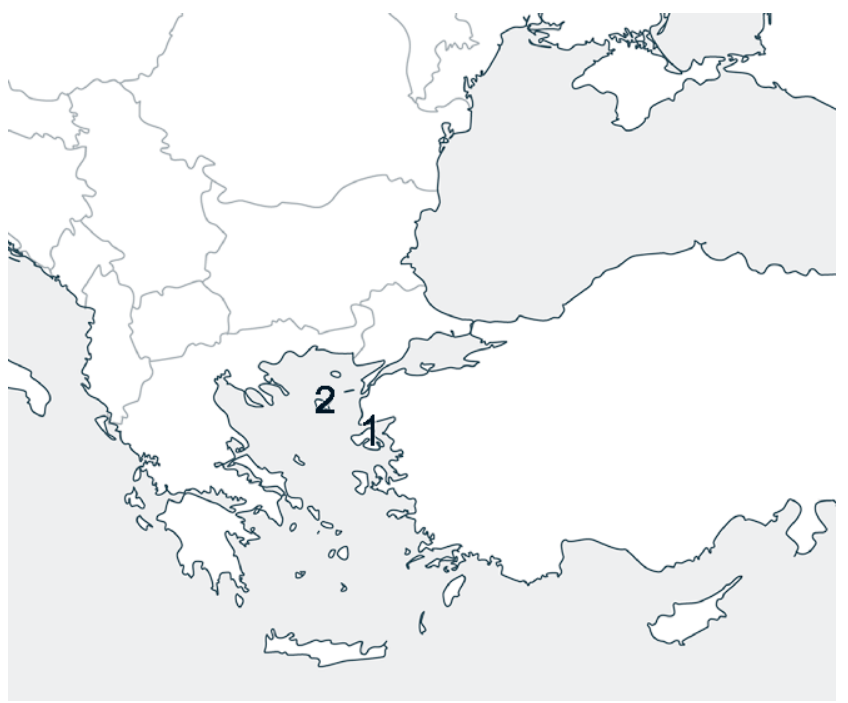

Text-fig. 1. Map of Greece with the geographical position of the studied localities. - 1: Lesbos Island (Damandri). - 2: Lemnos Island (Moudros).

and described in detail from a palaeoxylotomical, geological and stratigraphical point of view, along with new identification of 
the historical material from the western peninsula (Mantzouka et al. 2013, 2016, 2017, Mantzouka 2016). The fossil wood remnant studied here was found inside a volcanic layer of early Miocene age which is overlain by the Polichnitos ignimbrite (PU Unit), dated at 17.2 Ma (Borsi et al. 1972, Lamera 2004, Lamera et al. 2004) in the area of Damandri.

The geology of Lemnos Island was studied in detail by Roussos (1993). In his opinion, the sedimentary basement rocks can be divided into a) a Lower Unit (late Eocene to early Oligocene), which covers the largest part of the island, and b) an Upper Unit (early Oligocene). Towards the top, the Upper Unit is composed of terrestrial fluvial sediments (including conglomerates and sandstone). Half of the sedimentary basement of Lemnos Island is uncomformably overlain by lower Miocene volcanic rocks. The fossiliferous localities are found in the areas with lower Miocene volcanic tuffs. The fossil wood material studied in this paper comes from Moudros area which belongs to the Romanou Unit and is aged as 22.3 $\pm 0.7 \mathrm{Ma}$ (Pe-Piper et al. 2009).

\section{Material and methods}

Preparation of the thin sections was carried out in the Department of Historical Geology and Paleontology, Faculty of Geology and Geoenvironment, National and Kapodistrian University of Athens. Microscopic observations were made with an Olympus BX51 microscope, Olympus DP73 camera and QuickPHOTO MICRO 3.0 image analysis software. Anatomical descriptions follow the IAWA Hardwood List (IAWA Committee 1989). Each vessel was assessed separately, both for density and for vessel grouping percentage, as proposed by Wheeler (1986). Identification was made with reference to the InsideWood Web site (InsideWood 2004-onwards, http://insidewood.lib.ncsu. edu/search (last visit 5. 11. 2017); Wheeler 2011). Idioblast frequency was determined from transverse sections. The pith description follows the terminology proposed by Crivellaro and Schweingruber (2013). The material from Lesbos Island is housed at the Museum of Geology and Palaeontology in the National and Kapodistrian University of Athens and at the Natural History Collection of Vrisa - the Cultural, Research and Education Center of the National and Kapodistrian University of Athens. The studied material from Lemnos Island is housed in the Municipality of Moudros (Lemnos Island) and at the Museum of Geology and Palaeontology in the National and Kapodistrian University of Athens.

New names of plant fossils are being registered in the Plant Fossil Names Registry (PFNR), which is hosted and operated by the National Museum, Prague for the International Organisation of Palaeobotany (IOP), each with a unique registry number.

\section{Systematic palaeobotany}

Family Lauraceae Juss.

\section{Fossil Genus Cryptocaryoxylon LeISMAN}

Cryptocaryoxylon lesbium Mantzouka sp. nov. Pl. 1, Figs. 1-6

Holotype. Designated here. Specimen DM17 (Repository: Natural History Collection of Vrisa - Cultural,
Research and Education Centre of the National and Kapodistrian University of Athens), 3 slides (Repository: Museum of Geology and Palaeontology in the National and Kapodistrian University of Athens).

Plant Fossil Names Registry Number. PFN000086 (for new species).

E ty m o log y. The epithet, lesbium, is due to the origin of the described material (Lesbos Island, Greece).

Type horizon. Under Polichnitos Ignimbrite (PU unit), inside volcanic material.

A g e . Early Miocene.

Type locality. Damandri, Southeastern Lesbos, Greece.

D i a g n o s i s . Heteroxylous wood, growth rings present, diffuse porosity, numerous vessels per sq. mm; vessels generally in radial multiples of 2 to 4 , single and in clusters, circular to oval in outline, tyloses present; exclusively simple perforation plates; alternate intervessel pits, polygonal; non-septate fibres; paratracheal axial parenchyma, scanty; apotracheal axial parenchyma in marginal bands of up to a width of 3 cells; rays numerous, exclusively heterocellular, short to medium sized; mostly biseriate and triseriate; no aggregate rays present; idioblasts numerous, associated with the ray parenchyma cells only; no crystals present.

D e s c r i p t i o n . Macroscopic description. The sample is from a small stem of diameter $2.5 \mathrm{~cm}$ which was enclosed in volcanic material. It is silicified, light, porous, whitish and red-brown with distinct growth ring boundaries that can be seen with the naked eye.

Microscopic description. Pith: of square/rectangular or polygonal shape (Pl. 1, Figs 5, 6). - Growth rings: distinct (Pl. 1, Fig. 1). — Wood: diffuse-porous (Pl. 1, Fig. 1). Vessels: 40-100 (60-70) vessels/sq. mm.; $19 \%$ solitary, $50 \%$ in groups of two, $13 \%$ in groups of $3,2 \%$ in groups of 4 and $16 \%$ in clusters; tangential diameter 50 to $90 \mu \mathrm{m}$, mean: $70 \mu \mathrm{m}$; radial diameter of the solitary vessels 50 to $110 \mu \mathrm{m}$, mean: $80 \mu \mathrm{m}$; outline of solitary vessels round to oval (Pl. 1, Figs 1,2); vessel walls thin; perforation plates exclusively simple; tyloses common (P1. 1, Fig. 4); intervessel pits alternate and polygonal in outline, about $10 \mu \mathrm{m}$ across (medium to large in size). - Rays: heterocellular (Pl. 1, Fig. 3) 1 to 3 cells wide $(25-30 \mu \mathrm{m})$ (Pl. 1, Figs 2-4), commonly $2-3$-seriate and $180-550 \mu \mathrm{m}$ high, body of multiseriate rays composed of procumbent cells with one row of upright cells; no crystals observed; 13-20 (mean 15) rays per $\mathrm{mm}$. - Axial parenchyma: scanty paratracheal with a tangential width of 15-25 $\mu \mathrm{m}$, in marginal bands $1-3$ cells wide (Pl. 1, Fig. 2). - Fibres: most probably non-septate - Idioblasts: associated with the ray parenchyma cells only (P1. 1, Figs 2, 3); mean radial $\times$ tangential diameter of the idioblasts in transverse section: $12-30 \times 25-50 \mu \mathrm{m}$; number of idioblasts per sq. mm (transverse section): $35-45$.

Comparison with fossil wood. See Table 1. The anatomical characteristics of sample DM17 to some degree resemble Laurinoxylon genus Type 1 (Mantzouka et al. 2016), with idioblasts associated only with the ray parenchyma cells. The only feature (of great taxonomic 


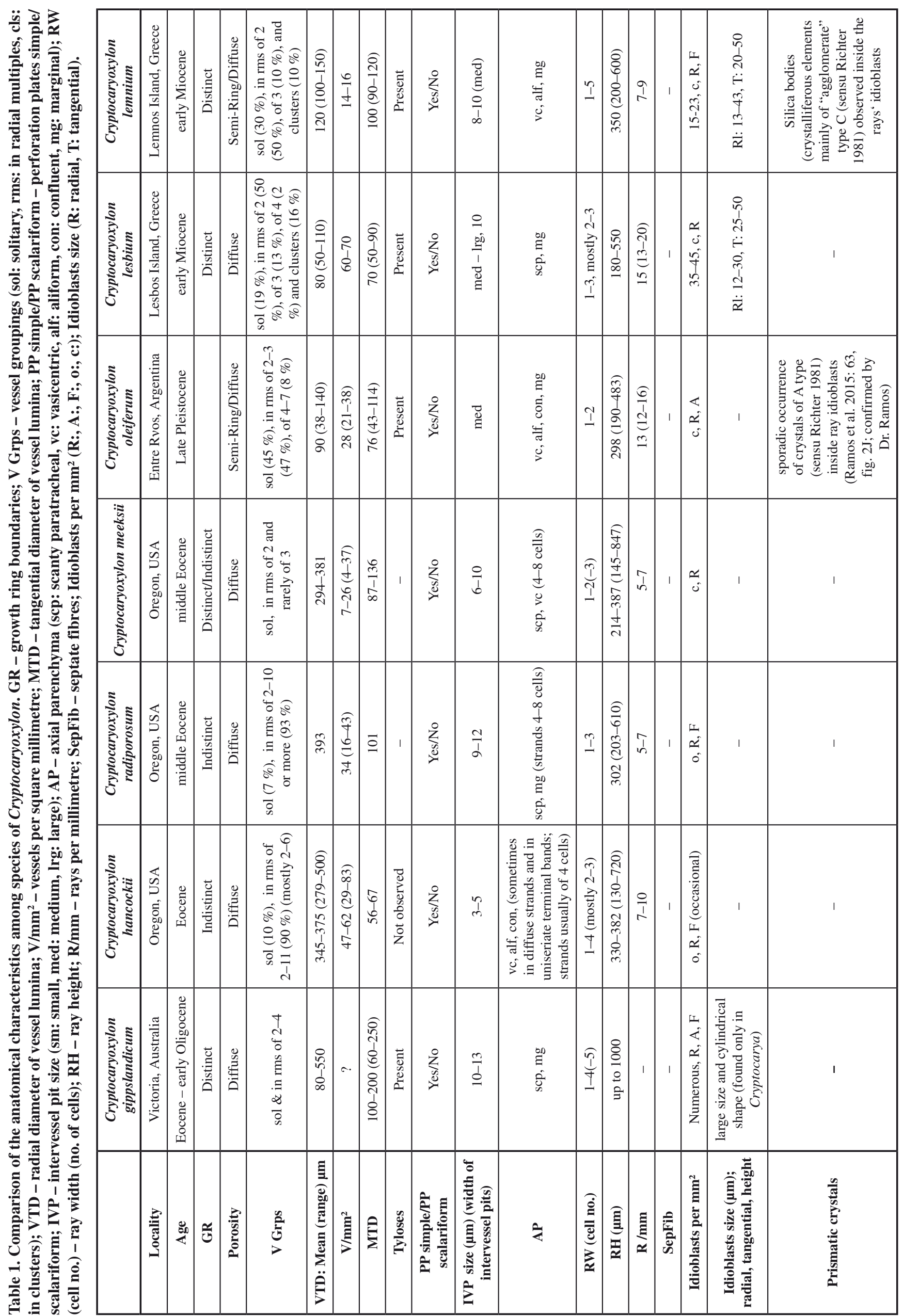


importance) not in accordance with the emended diagnosis of Laurinoxylon was the existence of axial parenchyma in marginal bands. The fossil Lauraceae include - with the exception of Laurinoxylon FELIX (previously also Laurinium UNGER, Ulminium UNGER and other genera) many other genera, such as: Beilschmiedioxylon DupÉronLAUDOUENEIX et Dupéron, Caryodaphnopsoxylon GotTwald, Cinnamomoxylon GotTwald, Cryptocaryoxylon LeISMAn, Mezilaurinoxylon WheELer et MANCHESTER, Paraperseoxylon Wheeler et MAnchester and Sassafrasoxylon BřezINová et Süss (Leisman 1986, Březinová and Süss 1988, Gottwald 1992, 1997, Wheeler and Manchester 2002, Dupéron-Laudoueneix and Duperon 2005). Based on the anatomical characteristics of modern Lauraceae wood as described by Richter (1981), we can say that the existence of marginal bands is the main characteristic of the tribe Cryptocaryeae NeEs, so the fossil genus Cryptocaryoxylon is similar to our sample. A comparison of DM17 and the already described representatives of this genus has indicated some differences (see Tab. 1) which support the delimitation of a new species.

B otanical affinities. Cryptocaryoxylon lesbium has axial parenchyma in marginal bands of up to a 3-cell width. Marginal bands are also found in the Cryptocaryeae NeEs tribe of the Lauraceae, thus the possible botanical affinities of our specimen include: Beilschmiedia, Endiandra, Potameia/Syndiclis, Triadodaphne, Cryptocarya, Ravensara, Licaria wilhelminensis. From the above-mentioned genera, we can exclude those which have different characteristics not in accordance with our sample: Endiandra contains species with idioblasts in the fibres, Potameia/Syndiclis and Triadodaphne don't have idioblasts in ray parenchyma, Ravensara has only species which contain A type crystals and Licaria wilhelminensis has only 1-row of parenchyma in marginal bands. So our sample could be closer to the present day genus Cryptocarya and more precisely to the $20 \%$ of species in this genus which have idioblasts in rays (only) and to an even more reduced percentage of species in this genus which have no crystals (Richter 1981). Taking into account the work by Richter (1981) and the vessel diameters in our specimen, we could hypothesise that our sample is more similar to Cryptocarya species from Chile than Cryptocarya species from New Guinea.

\section{Cryptocaryoxylon lemnium MANTzouka sp. nov.} P1. 1, Figs 7-15

H o lotype. Designated here. Specimen DMLHM11 (Repository: Municipality of Moudros, Lemnos Island), 3 slides (Repository: Museum of Geology and Palaeontology in the National and Kapodistrian University of Athens).

Plant Fossil Names Registry Number. PFN000087 (for new species).

Etymology. The epithet, lemnium, is due to the origin of the described material (Lemnos Island, Greece). Unit).

Type horizon. Inside volcanic tuff (Romanou

\section{A g e . Early Miocene.}

Type locality. Moudros, Central-Eastern Lemnos Island, Greece.

D i a g n o s i s. Heteroxylous wood, growth rings present, semi-ring/diffuse porosity, numerous vessels per sq. mm; vessels generally in radial multiples of 2 to 3 , also single and in clusters, circular to oval in outline, tyloses present; exclusively simple perforation plates; alternate intervessel pits, polygonal; non-septate fibres; paratracheal axial parenchyma, vasicentric to aliform and banded parenchyma with up to 3-cell wide rows and seemingly marginal bands; numerous rays, exclusively heterocellular, short to medium sized; mostly biseriate and triseriate, but up to a width of 5 cells; no aggregate rays present; idioblasts numerous, associated with ray parenchyma cells and among the fibres; silica bodies (crystalliferous elements / aggregate grains) inside rays' idioblasts.

D e s c ription. Macroscopic description. Part of a silicified stump, $15 \times 10 \times 8 \mathrm{~cm}(\mathrm{Pl}$. 1, Fig. 7).

Microscopic description. Growth rings: distinct (P1. 1, Fig. 8). — Wood: semi-ring/diffuse-porous (P1. 1, Fig. 8). Vessels: $14-16$ vessels/sq. mm.; $30 \%$ solitary, $50 \%$ in groups of two, $10 \%$ in groups of 3 and $10 \%$ in clusters; tangential diameter of the solitary vessels 90 to $120 \mu \mathrm{m}$, mean: 100 $\mu \mathrm{m}$; radial diameter of the solitary vessels 100 to $150 \mu \mathrm{m}$, mean: $120 \mu \mathrm{m}$; outline of solitary vessels round to oval (Pl. 1, Figs 8, 9); vessel walls thin; perforation plates simple ( $\mathrm{Pl}$. 1, Fig. 15); tyloses common (Pl. 1, Figs 8, 10); intervessel pits polygonal, alternate about $8-10 \mu \mathrm{m}$ (medium in size) (P1. 1, Fig. 11). - Rays: heterocellular (Pl. 1, Figs 11-14) up to 5 cells wide $(20-60 \mu \mathrm{m})(\mathrm{Pl}$. 1, Fig. 10), and 200 $600 \mu \mathrm{m}$ high (mean: $350 \mu \mathrm{m})(\mathrm{Pl} .1$, Figs 11, 12), body of multiseriate rays composed of procumbent cells with one row of upright and/or square marginal cells (Pl. 1, Fig. 14); silica bodies (crystalliferous elements) observed inside the rays' idioblasts (Pl. 1, Figs 11-14); 7-9 rays per mm. Axial parenchyma: vasicentric paratracheal to aliform with up to 3-cell wide rows (Pl. 1, Figs 8, 9) seemingly marginal bands of parenchyma (Pl. 1, Figs 8, 10) — Fibres: most probably non septate. - Idioblasts: associated with the ray parenchyma cells and among the fibres (P1. 1, Figs 11-14); mean radial $\times$ tangential diameter of the idioblasts in transverse section: $13-43 \times 20-50 \mu \mathrm{m}$; number of idioblasts per sq. mm (transverse section): 15-23.

Comparison with fossil wood. See Table 1. Our specimen belongs to the Lauraceae. The following characteristics of the specimen DMLHM11 are similar to Laurinoxylon Type 2b (Mantzouka et al. 2016): wood semi-ring-diffuse porosity, growth ring boundaries distinct, vessels mainly in radial multiples of $2-3$, often solitary but rarely in clusters, simple perforation plates and polygonal alternate intervessel pits medium size $(8-10 \mu \mathrm{m})$, tyloses common, paratracheal axial parenchyma vasicentric (to aliform), rays up to 5-seriate (mainly 2 -seriate), heterocellular, body of multiseriate rays composed of procumbent cells with one row of upright and/or square marginal cells, silica bodies (crystalliferous elements) observed inside rays' idioblasts and idioblasts associated with ray parenchyma and also among the fibres.

Our sample also has features not in accordance with the Laurinoxylon emended diagnosis, such as: a) paratracheal 
axial parenchyma vasicentric-aliform of up to 3-seriate bands wide, b) axial parenchyma being seemingly in marginal bands and c) the occurrence of idioblasts in rays (abundant) and in fibres (sporadic) along with the existence of silica bodies inside rays' idioblasts. The combination of features described above leads us to assign our specimen to Cryptocaryoxylon. The same result is obtained if we take into account Richter's classification (Richter 1981, 1987) based on the correlation of vessel-ray parenchyma pits and diameter classes of the intervessel pits, according to which our sample, DMLHM11, belongs to class b (with intervessel pits $8-12 \mu \mathrm{m}$, with vessel-ray pits variable in shape, round to oval, to elongate horizontally, vertically or diagonally).

DMLHM11 was compared with $C$. gippslandicum LEISMAN (Leisman 1986) from the Tertiary of eastern Victoria but there are differences concerning the intervessel pits' size, the apotracheal parenchyma, the exact location of the idioblastic cells, and the existence of siliceous inclusions in the material from Lemnos (Tab. 1).

Although the age of the findings in Nut Beds (Middle Eocene) is not particularly similar to ours (Early Miocene), we compared our specimen with Cryptocaryoxylon hancockii, $C$. radiporosum and $C$. meeksii and although there are a lot of similarities it seems that DMLHM11 is not identical with any of the latter species (Tab. 1). The major differences between Cryptocaryoxylon lemnium and C. hancockii are found in growth rings, vessel grouping, size and numbering, and intervessel pits' size. Cryptocaryoxylon lemnium and $C$. radiporosum differ in growth rings, vessel grouping, size and numbering, intervessel pit size, rays' width and exact location of idioblasts. A comparison of $C$. lemnium and $C$. meeksii revealed differences in vessel size (radial diameter), apotracheal parenchyma, rays' width, exact location of idioblasts and the existence of crystalliferous elements (silica bodies). Although there are also some "blobs" inside the rays' idioblasts in Cryptocaryoxylon radiporosum, which resemble silica bodies of C or even B type sensu Richter (1981) (Wheeler and Manchester 2002: 71, fig. 19F), they most probably represent residues of oils/extracts in the cells (Dr. Wheeler pers.com.). There are also differences when compared with C. oleiferum (Ramos et al. 2015) especially related to the idioblasts occurrence and crystals type (the sporadic occurrence of A type crystals inside rays' idioblasts in C. oleiferum was confirmed by Dr. Ramos, pers. com.).

Botanical affinities. Richter (1981, 1990) clarified the existence of axial paratracheal and marginal parenchyma. He described the occurrence of paratracheal, mostly abundant vasicentric to aliform, often confluent with multiseriate bands 2-6(-10) cells wide (Richter 1981: tab. 7, fig. 17a) in Beilschmiedia, Endiandra, Potameia/Syndiclis and Triadodaphne, the existence of paratracheal mostly sparse to slightly vasicentric multi-seriate bands 2-4(-8) cells wide (Richter 1981: tab. 7, fig. 17b) in Cryptocarya and Ravensara and the occurrence of paratracheal incomplete to closed vasicentric bands of exclusively one-line in Licaria wilhelminensis as well as marginal (or seemingly marginal), fine, up to three cell wide bands in L. subbullata (Richter and Dallwitz 2000-onwards: Commercial timbers: descriptions, illustrations, identification, and information retrieval. Version: 25th June 2009; http://delta-intkey.com.); the latter two species are apparently synonyms according to The Plant List (Version 1.1., published on-line in 2013; http://www. theplantlist.org/ (last visit 13. 9. 2017)). The occurrence of aliform to aliform-confluent paratracheal parenchyma has been observed in Hypodaphnis and Eusideroxylon (and/or Potoxylon, since some Eusideroxylon species have been moved to Potoxylon, and possibly Litsea garciae and $L$. sandakanensis) (Richter 1981).

Taking into account the latter characteristics along with the fact that $\mathrm{SiO}_{2}$ was observed in Beilschmiedia, Endiandra, Potameia, Triadodaphne inaequitepala, Cryptocarya, Mezilaurus, Licaria wilhelminensis, Litsea, Dehaasia, Endlicheria, Anaueria and Clinostemon (Richter 1981: tab. 11) we came to the conclusion that the closest modern genus is Cryptocarya which (according to Richter 1981) has the following characteristics: simple perforation plates, intervessel pits of $9-11 \mu \mathrm{m}$ in diameter, large distinct bordered pits in fibres which are horizontally layered, paratracheal vasicentric to aliform or to confluent parenchyma, terminal bands of parenchyma, (2-)3-5(-7)-celled rays, rays with a maximum height of $0.4-0.75-1.5 \mathrm{~mm}$, idioblasts mainly in rays but also in fibres, crystals of $\mathrm{A}$ type and $\mathrm{SiO}_{2}$ of "agglomerate" type C (found only in $15 \%$ of its species).

According to Carlquist (2001) the existence of $\mathrm{SiO}_{2}$ (silica bodies) is of relevance to wood anatomists because its presence is often of diagnostic value as only a minority of dicotyledonous woods contain visible silica accumulations. Representatives of the Lauraceae which contain silica according to the latter author are: Cryptocarya, Licaria, Mezilaurus, Ocotea.

Regarding silica bodies, the function as load-bearing structures, as strengthening elements when in connection with Young's modulus or perception as a beneficial element is still under research (Mosbrugger 1990, Channing and Edwards 2013). Future research into the occurrence of silica dioxide crystals and druses in fossil woods would help clarify what had been the function of these elements and their complexity.

From study of the wood anatomy in DMLHM11 we recognized that the occurrence of $\mathrm{SiO}_{2}$ (mainly "agglomerate" type C sensu Richter 1981) is mainly restricted to the interior of rays' idioblasts. This diagnosis, along with the previously described characteristics of our sample, leads us to assign our specimen to Cryptocaryoxylon. The result is also the same if we consider the classification by Richter $(1981,1987)$ based on a correlation of the vessel-ray parenchyma pits with diameter size classes of the intervessel pits. According to this classification our sample DMLHM11 belongs to class b (with intervessel pits $8-12 \mu \mathrm{m}$, with vessel-ray pits variable in shape, round to oval, to elongate horizontally, vertically or diagonally).

\section{Conclusion}

This is the first identification of the genus Cryptocaryoxylon from the Neogene of Eurasia. Until now Cryptocaryoxylon has been reported only three times: a) with the species Cryptocaryoxylon gippslandicum LEISMAN (Leisman 1986) from the late Eocene-Oligocene of Australia, b) with the species $C$. hancockii, C. meeksii 
and $C$. radiporosum WheELER et MANCHESTER (Wheeler and Manchester 2002) from the middle Eocene of North America and c) with the species Cryptocaryoxylon oleiferum RAmos, BrEA et KRÖHLING which has been found recently in the Late Pleistocene of Argentina (Ramos et al. 2015).

The modern genus Cryptocarya belongs to Cryptocaryeae NEES which is related to the Southern hemisphere tribe (Richter 1981, van der Werff and Richter 1996, Rohwer et al. 2014) in contrast to the Laurinoxylon species and Quercoxylon findings already described from Greece (Lesbos and Lemnos Islands, Eastern Mediterranean) which are related to the North hemisphere and the Asian/Neotropics genera. This information should be re-examined and evaluated in some future study to provide further information regarding palaeogeography, evolutionary trends in woods which formed the Miocene forest of Lesbos and Lemnos and the distribution of their present day representatives.

Finally, it is crucial that further research is directed towards the distinction between residues of oils/extracts and silica bodies which in fossil recrystallized woods (and especially in not well preserved specimens) appears problematic.

\section{Acknowledgments}

This research is sincerely dedicated to Professor Zlatko Kvaček, a great scientist who I admire, an inspiring, kind, helpful, open and generous teacher, a hard-working man passionate about palaeobotany and with whom I had the honor and privilege to learn, work and collaborate. Special thanks to the Institute of Geology and Palaeontology, Faculty of Science, Charles University, Prague, to Jiří Kvaček and the Palaeontological Department of the Natural History Section of the National Museum, Prague. I would also like to thank the Department of Historical Geology and Paleontology, Faculty of Geology and Geoenvironment, National and Kapodistrian University of Athens for permission to use their facilities for producing detailed anatomic descriptions and consequently taxonomic identification of the new material. Special thanks to Jakub Sakala and Marzena Klusek who reviewed this work and made significant comments and suggestions which greatly improved the present paper. Thanks also to Elisabeth Wheeler and Rita Soledad Ramos for their collaboration and scientific advice.

\section{References}

Borsi, S., Ferrara, G., Innocenti, F., Mazzuoli, R. (1972): Geochronology and petrology of recent volcanics in the eastern Aegean Sea (West Anatolia and Lesbos Island). Bulletin of Volcanology, 36: 473-493.

https://doi.org/10.1007/BF02597122

Březinová, D., Süss, H. (1988): Nadel- und Laubholzreste aus miozänen Hornsteinen von Lipnice, ČSSR. - Feddes Repertorium, 99: 279-289.

https://doi.org/10.1002/fedr.4910990709

Carlquist, S. (2001): Comparative Wood Anatomy. Systematic, Ecological, and Evolutionary Aspects of Dicotyledon Wood. - Springer Verlag, Berlin, Heidelberg, 450 pp.

Channing, A., Edwards, D. (2013): Wetland megabias: ecological and ecophysiological filtering dominates the fos- sil record of hot spring floras. - Palaeontology, 56(3): 523-556.

https://doi.org/10.1111/pala.12043

Crivellaro, A., Schweingruber, F. H. (2013) Atlas of wood, bark and pith anatomy of Eastern Mediterranean trees and shrubs with a special focus on Cyprus. - Springer Verlag, Berlin, Heidelberg, 583 pp.

Dupéron-Laudoueneix, M., Duperon, J. (2005): Bois fossiles de Lauraceae: nouvelle decouverte au Cameroun, inventaire et discussion. - Annales de Paléontologie, 91: 127-151. https://doi.org/10.1016/j.annpal.2005.03.002

Gottwald, H. (1992): Hölzer aus Marinen Sanden des Oberen Eozän von Helmstedt (Niedersachsen). - Palaeontographica, Abt. B, 225: 27-103.

Gottwald, H. (1997): Alttertiäre Kieselhölzer aus miozänen Schottern der ostbayerischen Molasse bei Ortenburg. Documenta naturae, 109: 1-83.

IAWA Committee (eds. Wheeler, E. A., Baas, P., Gasson, P. E.) (1989): IAWA list of microscopic features for hardwood identification. - IAWA Bulletin, n.s., 10: 219-232.

Lamera, S. (2004): [The Polychnitos Ignimbrite of Lesvos Island]; Ph.D. Thesis. - MS, Department of Geology and Geoenvironment, University of Patras, Greece, 265 pp. (in Greek)

Lamera, S., Tzortzi, J., Zelilidis, A., Seymour, K. S., Kouli, M. (2004): A Lahar-like Deposit at the Sole of the Polychnitos Ignimbrite, Lesvos Volcanic Field Northern Aegean, Hellas. - In: Proceedings of the $7^{\text {th }}$ International Conference of the Hellenic Geographical Society, Lesbos, Greece, pp. 408-414.

Leisman, G. A. (1986): Cryptocaryoxylon gippslandicum gen. et sp. nov., from the Tertiary of eastern Victoria. Alcheringa, 10: 225-234. https://doi.org/10.1080/03115518608619157

Mantzouka, D. (2016): Research of the Cenophytic Palaeoflora of the Eastern Mediterranean (Lesbos, Lemnos, Alonissos, Gavdos Islands); Ph.D. Thesis. - MS, Department of Geology and Geoenvironment, National and Kapodistrian University of Athens, Greece, 216 pp. (in English) (copy in library of School of Sciences, of the National and Kapodistrian University of Athens)

Mantzouka, D., Karakitsios, V., Sakala, J. (2016): Using idioblasts to group Laurinoxylon species - Case study from the Oligo-Miocene of Europe. - IAWA Journal, 37(3): 459-488.

https://doi.org/10.1163/22941932-20160147

Mantzouka, D., Karakitsios, V., Sakala, J., Wheeler, E. (2017): Cedroxylon lesbium (Unger) Kraus from the Petrified Forest of Lesbos, lower Miocene of Greece and its possible relationship to Cedrus. - Neues Jahrbuch für Geologie und Paläontologie, Abhandlungen, 284(1): 75-87. https://doi.org/10.1127/njgpa/2017/0653

Mantzouka, D., Sakala, J., Kvaček, Z., Karakitsios, V. (2013): Palaeobotanical study of Polichnitos region, Southern part of Lesbos Island, Greece (preliminary results on Angiosperm wood). - Bulletin of the Geological Society of Greece, 47(1): 204-215. https://doi.org/10.12681/bgsg.10928

Mosbrugger, V. (1990): The Tree Habit in Land Plants. A Functional Comparison of Trunk Constructions with 
a Brief Introduction into the Biomechanics of Trees. Lecture Notes in Earth Sciences, 28: 1-161.

Pe-Piper, G., Piper, D. J. W., Koukouvelas, I., Dolansky, L. M., Kokkalas, S. (2009): Postorogenic shoshonitic rocks and their origin by melting underplated basalts: The Miocene of Lemnos, Greece. - GSA Bulletin, 121(1/2): 39-54.

Ramos, R. S., Brea, M., Kröhling, D. M. (2015): Primer registro de Cryptocaryoxylon Leisman, una Lauraceae de la Formación El Palmar (Pleistoceno tardío), Entre Ríos, Argentina. - Revista del Museo Argentino de Ciencias Naturales, 17(1): 59-70.

Richter, H. G. (1981): Anatomie des sekundären Xylems und der Rinde der Lauraceae. - Sonderbände des Naturwissenschaftlichen Vereins in Hamburg, No. 5, 148 pp.

Richter, H. G. (1987): Mature secondary xylem. - In: Metcalfe, C. R. (ed.), Anatomy of the Dicotyledons, vol. 3., Magnoliales, Illiciales, and Laurales ( $2^{\text {nd }}$ ed.). Clarendon Press, Oxford, pp. 162-168.

Richter, H. G. (1990): Wood and bark anatomy of Lauraceae. III. Aspidostemon Rohwer et Richter. - IAWA Bulletin, n.s., 11(1): 47-56.

Rohwer, J. G., Moraes, P. L. R. de, Rudolph, B., Werff, H. van der (2014): A phylogenetic analysis of the Cryptocarya group (Lauraceae), and relationships of Dahlgrenodendron, Sinopora, Triadodaphne, and Yasunia. - Phytotaxa 158(2): 111-132. https://doi.org/10.11646/phytotaxa.158.2.1

Roussos, N. (1993): Geological map of Greece, Lemnos Island sheet. - Institute of Geology and Mineral Exploration of Greece, scale 1:50.000.

Werff, H. van der, Richter, H. G. (1996): Toward an improved classification of Lauraceae. - Annals of the Missouri Botanical Garden, 83: 409-418.

Wheeler, E. A. (1986): Vessels per square millimeter or vessel groups per square millimeter? - IAWA Bulletin, n.s., 7: 73-74. https://doi.org/10.2307/2399870

Wheeler, E. A. (2011): InsideWood: a web resource for hardwood anatomy. - IAWA Journal, 32: 199-211. https://doi.org/10.1163/22941932-90000051

Wheeler, E. A., Manchester, S. (2002): Woods of the Middle Eocene Nut Beds, Clarno Formation Oregon, USA. - IAWA Journal, Supplement 3: 1-188.

\section{Explanations of plates}

\section{PLATE 1}

Cryptocaryoxylon lesbium MANTzouka sp. nov. (DM17)

1. Growth rings distinct, diffuse-porous wood.

2. Growth rings distinct, wood diffuse-porous, outline of solitary vessels round to oval, rays up to 4-seriate, idioblasts: associated with the ray parenchyma cells, axial parenchyma in marginal bands.

3. Idioblasts: associated with the ray parenchyma cells (usually at the edges of the rays, but also within their body).

4. Vessels with common tyloses.

5,6 . Pith of square/rectangular or polygonal shape.

Cryptocaryoxylon lemnium MANTZOUKA sp. nov.(DMLHM11)

7. The dimensions of the specimen are: $15 \times 10 \times 8 \mathrm{~cm}$.

8. Growth ring boundaries distinct, semi-ring/diffuseporous wood, vessels in multiple groups of up to 3 and in clusters, tyloses common, 7-9 rays per millimeter, vasicentric paratracheal to aliform parenchyma, seemingly marginal bands of parenchyma.

9. Solitary vessels' outline round to oval, vasicentric paratracheal to aliform parenchyma, with rows up to 3-cells in width.

10. Rays heterocellular up to 5 cells wide, idioblasts associated with the ray parenchyma cells and among the fibres.

11. Idioblasts associated with the ray parenchyma cells and among the fibres, perforation plates simple, intervessel pits: polygonal alternate and medium in size.

12. Rays $200-600 \mu \mathrm{m}$ high, idioblasts associated with the ray parenchyma cells and among the fibres, silica bodies (crystalliferous elements) observed inside the rays' idioblasts.

13,14 . Body of multiseriate rays composed of procumbent cells with one row of upright and/or square marginal cells, idioblasts associated with the ray parenchyma cells and among the fibres, silica bodies (crystalliferous elements) observed inside the rays' idioblasts.

15. Perforation plates simple.

Scale bar $=50 \mu \mathrm{m}$ in $2,3,6,10 ; 100 \mu \mathrm{m}$ in $4,9,11,12,13$, 14,$15 ; 500 \mu \mathrm{m}$ in 5,$8 ; 1,000 \mu \mathrm{m}$ in $1.1,2,5,6,8,9,10$ $=\mathrm{TS} ; 13,14,15=\mathrm{RLS} ; 3,4,11,12=\mathrm{TLS}$. TS, RLS and TLS denote transversal, radial and tangential longitudinal sections, respectively. In addition, IR denotes Idioblasts associated with Rays (IR) and IF denotes Idioblasts associated with Fibres (IF). MB denotes axial parenchyma in Marginal Bands (MB). 
PLATE 1

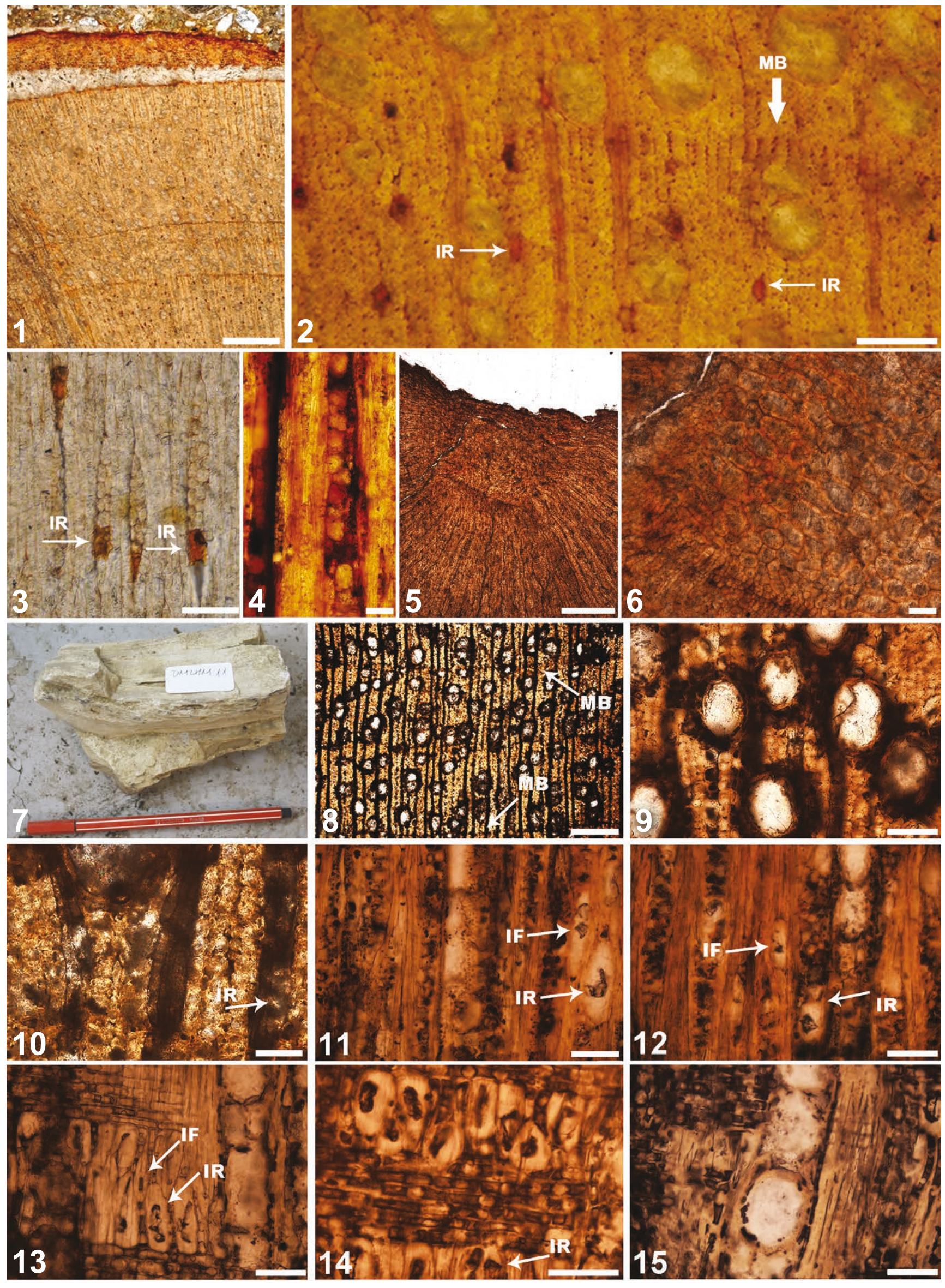

